\title{
Kontra Miklós*
}

\section{HOGYAN LEHET, HOGY AZ AKADÉMIÁTÓL A KOCSMÁROSOKIG MINDENKI TÁMOGATJA A MAGYAROK MAGYAROK ÁLTALI NYELVI DISZKRIMINÁCIÓJÁT?**}

\author{
Kulcsszavak: nyelvi diszkrimináció, lingvicizmus, magyar nyelvmüvelés, kodifikált standard \\ magyar nyelvváltozat, Kárpát-medencei magyarok, iskolai nyelvtanórák, \\ felcserélő és hozzáadó nyelvpedagógia, tanárképzés
}

Nem lennék meglepve, ha valaki, aki ennek az előadásnak a címét hallja vagy olvassa, kapásból elutasítaná a címbe foglalt állításomat, nevezetesen, hogy a Magyar Tudományos Akadémia és szinte minden magyar ember támogatja a magyarok magyarok általi nyelvi diszkriminációját. Az se lepne meg, ha az elutasítók felháborodottan, indulatosan hangoztatnák ellenvéleményüket. Hiszen nem kevesebbet állítok, mint hogy a Magyar Tudományos Akadémia, amit „a nemzet a magyar nyelv ápolására, a tudomány szolgálatára hoz[ott] létre” ${ }^{1}$, támogatja a magyarok nyelvi diszkriminációját, és ezt a tevékenységét (szinte) össztársadalmi helyeslés övezi.

\section{TÉNYLEG TÁMOGATJÁK?}

A magyar jogszabályok között nem az Akadémiáról szóló törvény az egyetlen, amely nyelvünk ápolásáról rendelkezik. Itt van például Magyarország Alaptörvénye (2011. április 25.), ennek elején ez áll: „Vállaljuk, hogy örökségünket, egyedülálló nyelvünket, a magyar kultúrát, a magyarországi nemzetiségek nyelvét és kultúráját, a Kárpát-medence természet adta és ember alkotta értékeit ápoljuk és megóvjuk.” A magyarországi Nemzeti alaptanterv (lásd a 110/2012. (VI. 4.) kormányrendeletet)² egyebek mellett megköveteli az „alapvető nyelvhelyességi, helyesírási ismeretek tudatos alkalmazását” és a „nyelvhelyességi problémák önálló

* Kontra Miklós a Szegedi Tudományegyetem nyelvészprofesszora. 1985 és 2010 között az MTA Nyelvtudományi Intézetében a szociolingvisztikai (élőnyelvi) kutatások vezetője volt. Fő kutatási területei: a magyarországi magyar nyelv változatai, a határon túli magyarok kétnyelvúsége, amerikai-magyar kétnyelvűség és nyelvi emberi jogok. kontra@lit.u-szeged.hu

* Köszönöm Cseresnyési Lászlónak, Imre Lászlónak, Kovács Andrásnak, Margócsy Istvánnak és Tolcsvai Nagy Gábornak, hogy e szöveg egy korábbi változatát elolvasták, megkritizálták. Természetes, hogy nem mindenben értenek velem egyet. Azt is készséggel elismerem, hogy ez a téma sokkal bővebb kifejtést érdemelne, de hát a kolozsvári konferencián csak ilyen rövid előadásra volt lehetőségem.

1 Lásd A Magyar Tudományos Akadémiáról szóló 1994. évi XL. törvény módosításáról szóló 2009. évi XX. törvényt.

2 Magyar Közlöny 2012. évi 66. szám. 
megoldását (szóban és írásban egyaránt).” S ne feledjük, hogy a magyar országgyúlés egy 2011. szeptemberi határozatával fölkérte a kormányt, hogy „a szakmai és társadalmi nyilvánosság bevonásával vizsgálja meg nemzeti nyelvünk használatának helyzetét, s ennek alapján készítsen elő intézkedési tervet a magyar nyelv értékeinek védelme, korszerű továbbfejlesztése és népszerüsítése céljából". ${ }^{3}$

A politikusok megszólalásaiból legyen elég csupán két idézet, mindkettőt a magyarországi köznevelésért felelős államtitkár azon beszédéből választottam, ${ }^{4}$ amelyet az MTA Nyelvtudományi Intézetének helyesírási tanácsadó portálja bemutatóján mondott 2013 áprilisában:

(1) „Magyar nyelvünk, a helyesírásunk a mi saját kincsünk. Az az ember, aki saját kincsét, a rábízott értéket nem ápolja, nem gyarapítja, az vétkes.”

(2) „Manapság tanúi vagyunk annak, és ez néha fájdalmas élményt is jelent nekünk, hogy kopik, romlik a nyelvünk, így van ez egyébként világszerte.”

$\mathrm{Az}$ (1) idézet kapcsán föltehetjük azt a kérdést, hogy vajon hányan vannak a magyarok közt a vétkesek? A (2) kapcsán pedig jó, ha tudjuk, hogy a köznevelésért felelős államtitkár s a magyarok túlnyomó többsége által használt „nyelvromlás” tudományos szempontból értelmezhetetlen. ${ }^{5}$

A magyar nyelvművelés, amelyben az Akadémiának jelentős szerepe volt és van ma is, az utóbbi negyed században viták kereszttüzébe került, tudományos szempontból és társadalmi következményei miatt többen megkérdőjelezték működését. ${ }^{6}$ A nyelvészek többé-kevésbé

3 Más kérdés, hogy a Nemzetpolitikai Államtitkárság által készített „Magyar nemzetpolitika: A nemzetpolitikai stratégia keretei” címú iratban (Budapest, Közigazgatási és Igazságügyi Minisztérium, Nemzetpolitikai Államtitkárság, a szerkesztésért felelős: Répás Zsuzsanna) „A külhoni magyarok vonatkozásában” szereplő 15 cselekvési terület között szerepel számos terület a demográfiától a mezőgazdaságon át a sportig, de a magyar nyelv nem. Megemlítem még, hogy a kisebbségi magyarok szempontjából legfontosabb nyelvészeti kutatásokat végző Termini Magyar Nyelvi Kutatóhálózat (lásd pl. A Termini Magyar Nyelvi Kutatóhálózat tíz éve: Tanulmányok, beszámolók, kutatási programok. Szerk. Benő Attila-PÉntek János: Gramma Nyelvi Iroda-Szabó T. Attila Nyelvi Intézet, Dunaszerdahely-Kvár, 2011.) a mai napig nem került be a magyar kormányok által támogatott „nemzeti jelentőségű intézmények” közé - amelynek számtalan oka lehet, de egy biztos nem: szakmai-tudományos. (2012-ben 56 ilyen intézmény kapott normatív támogatást, a Termini viszont kis összegű MTA-pályázatokból tengődik.)

4 Hoffmann Rózsa: A magyar nyelv, a magyar helyesírás közös kincsünk. 2013. április 30. http://www. kormany.hu/hu/emberi-eroforrasok-miniszteriuma/oktatasert-felelos-allamtitkarsag/videok/ hoffmann-rozsa-a-magyar-nyelv-a-magyar-helyesiras-kozos-kincsunk

5 É. KIss Katalin: A „nyelvromlás”- egy szinkron szempontból értelmezhetetlen nyelutörténeti metafora = Az Üveghegyen innen: Anyanyelvváltozatok, identitásés magyar anyanyelvi nevelés. Szerk. Cser NICs Kó István-Kontra Miklós, PoliPrint Kft és II. Rákóczi Ferenc KMF, Ungvár-Beregszász, 2008. $17-$ 29.

6 Lásd például: Cseresnyési László: Anyanyelvünk démonjai. Élet és Irodalom 2011. március 25., 13.; Nyelvmentés vagy nyelvárulás?: Vita a határon túli magyar nyelvhasználatról. Szerk. KonT RA Miklós-Saly Noémi, Bp., Osiris, 1998.; Lanstyák István: Helyi „értékes” nyelvváltozatok, „tisztes” idegen szavak, „visszás” jelentések, „agresszîv” röviditések, „kevercs” nyelv és társaik. Válogatás a nyelvmüvelói csacskaságok gazdag tárházából, I-II. Fórum Társadalomtudományi Szemle 2003/4: 69-98. és 2004/1: 51-76.; SÁNDOR Klára: Nyelvmúvelés és ideológia = Uő, szerk.: Nyelv, nyelvi jogok, oktatás: Tanulmányok a társasnyelvészet oktatásáboz. Szeged,JGYF. 153-216. (a továbbiakban Sándor szerk. 2001); Uő: Hányan tudnak magyarul - helyesen? - huszonhetedik rész. www.galamuscsoport.hu/ 
két csoportra oszlanak: egy olyan skálán helyezkednek el, amelynek egyik végpontján az elóiró szemlélet hívei vannak (ők megmondják, mi a helyes s mi a helytelen, s tanácsaik, előírásaik maradéktalan betartását várják el mindenkitől), a másik végponton levốk a leiró szemléletet preferálják (ők a helyes-helytelen fogalompár helyett legfeljebb helyénvaló, illetve nem helyénvaló nyelvhasználatról beszélnek). E két szemlélet békétlen egymás mellett élése néha akadémiai skizofréniát is szül. Például a 2001. évi úgynevezett „reklámnyelvtörvény” parlamenti szavazása előtt az MTA Nyelvtudományi Intézetének igazgatója és több kutatója ${ }^{7}$ nyilvánosan kijelentette, hogy nem kívánnak részt venni tudományosan eldönthetetlen kérdések eldöntésében (vagyis abban, hogy megállapítsák, mi számít a magyar nyelvben meghonosodott idegen nyelvú kifejezésnek s mi nem), de miután az országgyúlés megszavazta a törvényt, az Intézet a ráosztott feladatnak engedelmesen megfelelt s megfelel mindmáig (vagyis eldöntötte s eldönti ma is a tudományosan eldönthetetlen kérdéseket is). Amint honlapjukon írták: „tudományosan megalapozott nyelvi tanácsadással” szolgáltak például az idegen nyelvű kifejezések meghonosodottsága tekintetében, $30000 \mathrm{Ft}$ + áfa díjazásért (http://www.nytud. hu/ril/nyelvitan.htm, 2004. július 14.). Ugyanezt a szolgáltatást 2013. november 8-án 50000 Ft + áfáért nyújtották.

A magyarok nagyrészt a standard nyelv kultúrájában élnek, ${ }^{8}$ vagyis a magyar társadalmakban a standard nyelvváltozat (a kodifikált standard) felsőbbrendúségét különböző csatornákon hirdetik (ebbe beleértve az írás-olvasás tanítását is), ennek a felsőbbrendủ változatnak a fontosságát az emberek tudatába plántálják, és e tudást fenntartják, átörökítik.

Ami a kodifikált standard magyar nyelvváltozatot illeti, arról tudjuk, hogy a magyarországi lakosság nagy része (kétharmada, de esetenként $90 \%$-a) se a nyelvi helyesség megítélésében, se saját beszédében nem képes megfelelni a tanítók, tanárok és nyelvművelők elvárásainak. ${ }^{9}$ Kirívó, szörnyú eset az akadémiai helyesírási ${ }^{10}$ szabályzat 11 . kiadásának az a szabálya, mely szerint az útitárs szót hosszú $u$-val kell írni, ugyanis a 767 fôs országos reprezentatív mintánknak csupán 2,4\%-a javította írásbeli hibajavító feladatban az utitárs-at a szabályzat megkövetelte útitárs-ra. Ez tehát egy olyan szabály, amit a magyarországi felnőtt írástudó magyarok 97\%-a nem tud alkalmazni. Képzeljük el, milyen legitim diszkriminációs eszközt alkalmaznánk, ha álláshirdetésre jelentkezőktől olyan kézzel írt motivációs levelet kérnénk, amelyben

tartalom/cikk/139994 (2012.05.26. 04:33); Szilágyi N. Sándor: Nincs olyan, hogy A Magyar Nyelv. (T. Koós Imola interjúja) http://maszol.ro/index/php/kultura/20688-szilagyi-n-sandor-nincsolyan-hogy-a-magyar-nyelv. 2013. november 12.; ToLCsvaI NAGY Gábor: Nyelvárulás és nyelvmentés: kánon vagy diskurzus? Magyar Nyelvőr 118(1994): 385-398.

7 Kiefer Ferenc: Nyelv és tudomány. Népszabadság 2001. november 30., 20. lap.; DANiss Győző: Kétfrontos nyelvvédelem. Az Országgyúlés fog dönteni a T/4899. számú törvényjavaslatról. Népszabadság 2001. október 6., 26-27. lap.

8 Lásd: Milroy, James: The consequences of standardisation in descriptive linguistics = Bex, TonyRichard J. WAтts, eds., Standard English: The widening debate, London/New York, Routledge, 1999. 16-39.

9 Lásd: Nyelv és társadalom a rendszerváltáskori Magyarországon. Szerk. Kontra Miklós, Osiris, Bp., 2003. (a továbbiakban KonTra szerk. 2003)

10 „A helyesírás nemzeti önazonosságunk része, látható, őrizhető jele, a nemzet összetartó kapcsa, olyan, mint a magyar zászló vagy a himnusz" - írta Minya Károly: Magyar helyesírási szótár. Magyar Nyelvőr 123(1999): 496-498. *** Köszönöm Cseresnyési Lászlónak, hogy fölhívta figyelmemet erre az általam korábban nem ismert kinyilatkoztatásra. 
használniuk kéne egy olyan szót, amelyre vonatkozik $A$ magyar helyesírás szabályai tizenegyedik kiadásának ${ }^{11} 27$. b) pontja!

Egy negyed századdal ezelőtti magyarországi reprezentatív vizsgálatból tudjuk, hogy az akkori felnőtt írástudó lakosságnak kétharmada nem felelt meg a tanítók, tanárok és nyelvmúvelők által elvárt, megkövetelt „helyes” beszéd kívánalmainak. Az 1. ábra azt mutatja meg, hogy szóbeli mondatkiegészítő feladatok végzésekor a teljes mintából $(\mathrm{N}=832)$ hányan maradtak, miután hét feladatot is a kodifikált standardnak megfelelő módon oldottak meg. Láthatjuk, hogy 832-ből 700-an maradtak, miután az NY302-es mondatot (Azt akarom, hogy ó ... ki az ajtót.) a standard nyissa szóalakkal egészítették ki (vagyis nem a túlhelyesbített, hiperkorrekt nyitja-val). A hetedik feladat után a teljes mintából már csupán 290-en maradtak, vagyis a minta 34,8\%-a tudott csak megfelelni „a helyes beszéd” kívánalmainak. Másképp mondva ez azt jelenti, hogy az iskolai tanítók, tanárok és a nyelvmúvelők az 1988. évi magyarországi felnőtt lakosság kétharmadát „vették célba”. Pontosabban fogalmazva: azok a tanítók és tanárok, akik betartották azt az előírást/elvárást, hogy az 1. ábra feladatait „helyesen” oldják meg a diákok, a tanulók kétharmadát „vették célba” (föltéve, hogy a gyermekek a szüleiktől otthon tanult magyart beszélve érkeztek az iskolába).

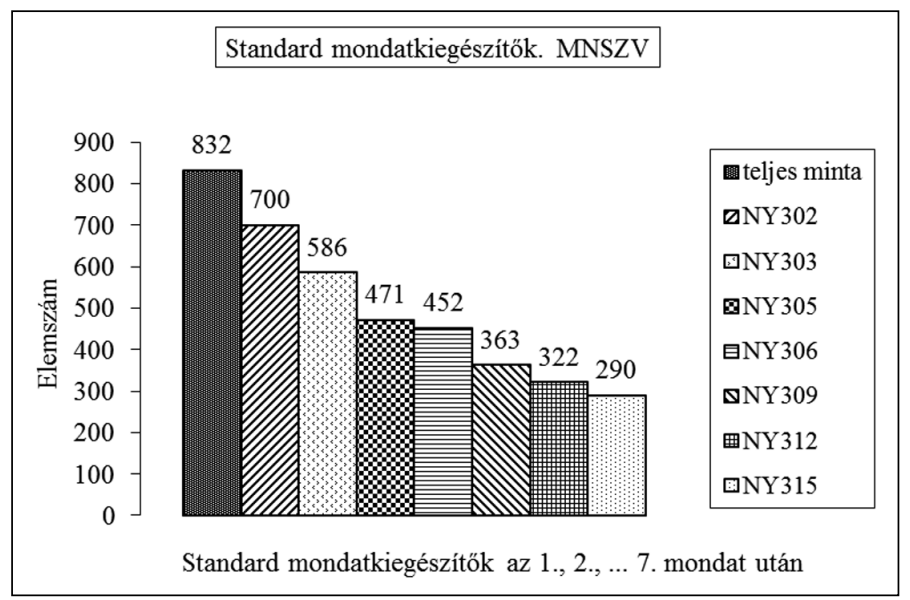

1. ábra. Standard szóbeli mondatkiegészítők, Magyar Nemzeti Szociolingvisztikai Vizsgálat (MNSZV), 1988, N = 832 (KontrA szerk., 2003. 217, 5.40. ábra)

NY302 Azt akarom, hogy ő [nyissa] ki az ajtót.

NY303 Ha jobb lenne a fizetésem, többet is [tudnék] dolgozni.

NY305 Az asztalos éppen most [ragasztja] a szék lábát.

NY306 Ebben a zajban nem hallom, ha Éva [kinyitja] az ajtót.

NY309 [Természetes] hogy igazad van mindenben.

NY312 Nem akarom, bogy Tamás a rossz utat [válassza].

NY315 [Természetesen] igazad van, mint legtöbbször.

11 A magyar helyesírás szabályai. Akadémiai, Bp., 1984. 
Mindannyian tudjuk, hogy ha valaki azt mondja, hogy Nem hallom, ha Éva kinyissa az ajtót, akkor suksüköl, amiért sokan megszégyenítik, s van, aki az így beszéló embert szellemileg visszamaradottnak tartja. Ha meg azt mondja valaki, hogy én többet is tudnák dolgozni, akkor „a magyar nyelvtan elleni vétséget követ el”. Röviden mondva: a kodifikált standardtól eltérő nyelvi szerkezeteket, szavakat és kiejtést a magyarok szívesen stigmatizálják, s az ilyen megbélyegző kijelentéseik gyakran nem is a nyelvi szerkezetekre, hanem azok használóira vonatkoznak („aki így beszél, nem is lehet igazi, rendes magyar ember”). Az ilyen kijelentéseket a standard nyelvi kultúrában élő magyarok zöme nem hogy nem helyteleníti, sokkal inkább helyesli: úgy vélik, aki nyelvünk tisztaságát, helyes használatát védi, az nemzetünket gyámolítja.

A kodifikált standard magyar változat még ma is túlzottan Magyarország-központú, ezért esetenként stigmatizálják a határon túli magyarok nyelvhasználatát. Például az el kell menjek szerkezetet a Nyelvművelő kéziszótár „eredetileg tájnyelvi, a köznyelvben bizalmas-népies v. bizalmas-pongyola hatású"-nak nevezi. ${ }^{12}$ Nem véletlen, hogy Péntek János ezt a szerkezetet „megbélyegzett transzszilvanizmusnak” hívta. ${ }^{13}$ Magam Budán nőttem föl, erdélyi származású magyartanár édesanyámtól tanultam ezt a szerkezetet, s öntudatlanul használtam mindaddig, amíg az 1990-es évek (tehát 40-es éveim) közepén egy kéziratomat megkérdezésem nélkül úgy össze nem karistolta az Akadémia Nyelvtudományi Intézetében egy osztályvezető kollégám, hogy nem ismertem rá. Minden egyes kell legyen-emet átjavította kell lennie-re, minek következtében a korrektúra olvasásakor az volt a határozott érzésem, hogy bizonyos mondatokat nem én írtam.

Kárpát-medencei magyar vizsgálatainkból tudjuk, hogy például a Mari is meg kell oldja a saját problémáit mondat helyességének megitélésében a magyarországiak statisztikailag jelentősen eltérnek az erdélyiektől, amint azt a 2 . ábra mutatja.

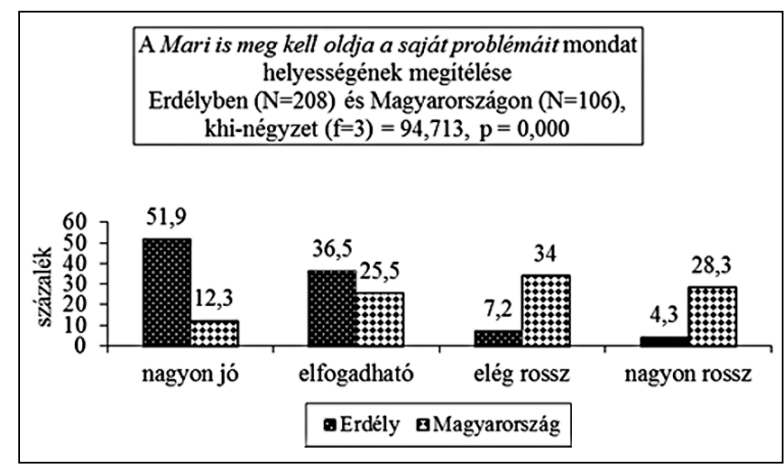

2. ábra. A Mari is meg kell oldja a saját problémáit mondat helyességének megítélése Romániában és Magyarországon ${ }^{14}$

12 Nyelvmúveló kéziszótár. Második, javított és bővített kiadás. Szerk. Grétsy László-Kemény Gábor, Tinta, Bp., 2005. 288.

13 PÉnTEK János: Egy megbélyegzett transzszilvanizmusról = Nyelvét megtartó közösség - közösségét megtartó nyelv: Az AESZ két évtizede a nyelvi közösség szolgálatában. Szerk. ERDÉLY Judit-ÖRDöGGyárfás Ágnes-Ördög-Gyárfás Lajos-PÉntek János, Anyanyelvápolók Erdélyi Szövetsége, Sepsiszentgyörgy 2012. 283-284. [Első megjelenés: 1999]

14 Kontra Miklós-PÉntek János-Szilágyi N. Sándor: A Kárpát-medencei szociolingrvisztikai vizsgálat 1996. évi romániai kérdōive és kereszttáblái (II.). Nyelv- és Irodalomtudományi Közlemények 2011/1: 67-84. (K_524-es kereszttábla a 73. oldalon) 
Tegyük ehhez hozzá, hogy erdélyi adatközlőink helyességi ítéleteire se életkoruknak, se nemüknek, se iskolázottságuknak nem volt statisztikailag jelentős hatása, vagyis a kell legyen szerkezet helyesnek ítélése minden társadalmi csoportban jelentősen eltér a magyarországi ítéletektôl.

\section{TUDATOSAN DISZKRIMINÁLNAK?}

Fell kell tegyük azt a kérdést (a nyelvhelyesség magyarországi őrei kedvéért fel kell tennünk), hogy vajon azok, akik a nyelvi helyesség (vélt) kívánalmainak érvényesítését szorgalmazva társadalmi diszkriminációt múködtetnek, tudatosan teszik-e, amit tesznek. Az a benyomásom (tudományos vizsgálatot még nem végeztek erről), hogy a zömüknek fogalmuk sincs a nyelvi alapú társadalmi diszkrimináció múködésérôl. Van viszont olyan tapasztalatom, hogy amikor valaki megismeri az idevágó tényeket, önkritikát gyakorol, s például megváltoztatja tanári hibajavító metódusait. ${ }^{15}$

Kétségtelen azonban, hogy vannak esetek, amikor a nyelvhelyesség őrei tudatosan bocsátkoznak társadalmi diszkriminációba. Egy diákom mesélte évekkel ezelőtt, hogy egy kézzel írt kérvényt nyújtott át egy egyetemi vezetőnek, aki rápillantva a papírra, így szólt: Ha ilyen hibát tartalmazó kérvényt ad nekem, megtehetném, hogy olvasás nélkül elutasitom. Annak a szolnoki rádiónak a vezetóje is tudatosan diszkriminált, aki „parasztos beszéde” miatt nem vett föl egy újvidéki bemondót, mivel az illető középzárt $\ddot{e}$-vel beszélte anyanyelvét. ${ }^{16}$ Tudatos nyelvi alapú társadalmi diszkriminációt követ el például az a fizikatanár is, aki gimnáziumi tanulmányokra alkalmatlannak minősít egy olyan jelentkezőt, aki iszok-ot mond, sőt még a Petőff-t is, névelővel. Diszkriminációs gyakorlatáról számolt be az Országos Szórakoztató Zenei Központ vezetője is, amikor 2006-ban így nyilatkozott: Ha egy diszkós suksüköl, akkor eltanácsoljuk. ${ }^{17}$

Azt is megkérdezhetjük, hogy tudatosan stigmatizálják-e egymást a magyarok? Az a tanár, aki kinevettette osztálytársaival azt a kisgimnazistát, aki celefán-t mondott celofán helyett, tudatosan szégyenítette meg diákját. ${ }^{18} \mathrm{Ha}$ egy tanuló iskolai órán véletlenül azt mondja, hogy aludva, s tanára erre így reagál: Mi van, Bunkóéknál így mondják?, akkor tudatosan tapos a diák lelkébe. A magyar iskolákban zajló nyelvi alapú lélekrombolást pontosan diagnosztizálta Papp István ${ }^{19}$ már közel 80 évvel ezelött:

„A legelső dolog, ami a gyermeket meglepi az iskolában, az, hogy az a magyar nyelv, melyet otthon tanult az édesanyjától, s melyet szülei, testvé-

15 Amikor a Bolyai Nyári Akadémia magyar nyelvészeti tanfolyamait tartottuk 1996 és 2001 között Csíkszeredában (lásd pl. SÁNDOR Klára szerk.: Nyelv és hatalom, nyelvi jogok és oktatás: Tanulmányok a Bolyai Nyári Akadémia elóadásaiból. Csíkszereda, „Apáczai Csere János” Pedagógusok Háza, 2000), számos magyartanár szembesült saját jó szándékú, de káros gyakorlatával, s voltak, akik nyilvánosan is beszámoltak arról, hogy „teljesen átértékelték eddigi tanári munkájukat.”

16 Lásd: Kontra Miklós: Hasznos nyelvészet. Fórum Kisebbségkutató Intézet, Somorja, 2010. 112. (a továbbiakban KonTra 2010.)

17 Lásd: Kontra 2010. 81.

18 Lásd: Kontra 2010.57.

19 PApp István: A magyar nyelvtan nevelöereje. Királyi Magyar Egyetemi Nyomda, Bp., 1935. 16-17. 
rei és játszótársai beszélnek, nem helyes, hanem szégyelnivaló. Minden erejét összeszedi hát, hogy egy-kettőre elfelejtse szülőfaluja parasztos beszédmódját, mely az első napokban annyi pirulást és lelki gyötrelmet szerzett neki.El is felejti mihamar, s ha késóbb felnőtt korában a gyermekkori anyanyelv hangja találja megütni fülét, rögtön feltámad lelkében az első iskolai napok szorongó, kellemetlen érzése. Ez az érzés fogja színezni lelkében állandóan szülőfaluja nyelvjárásának képét, s hogy megszabaduljon a kellemetlen emlékektől, igyekezni fog fölé emelkedni gúnnyal és megvetéssel. Meggondolták-e az iskola emberei, mit romboltak itt a növendék lelkében?"

Az ilyen iskolai rombolást néhány szépírónk is megörökítette. Ismeretes, miként alázták meg és gúnyolták ki Illyés Gyulát ${ }^{20}$ egy mértanórán, amikor egy egyenest húzott „a bé és áff pontok között”, de megrázó élményéről számolt az 1960-as években Simon István is. ${ }^{21}$

Az iskolai nyelvtanórákról Margócsy ${ }^{22}$ sajnálatosan precízen állapította meg, hogy „ma az anyanyelv oktatásának nem az a funkciója, hogy felkészítsen a magas szintú, múvelt, írásbeli, sok múfajban is érvényesülni tudó nyelvhasználatra, hanem az, hogy csak szabályozza és standardizálja a beszédet és az alapszintủ fogalmazást, azaz (mai értelemben vett) nyelvmüvelő funkciót lásson el." Amikor az iskolában nem hozzáadó, hanem felcseréló anyanyelvi nevelés ${ }^{23}$ zajlik, akkor a diákok nyelvhasználatát és magukat a diákokat is megbélyegzik a tanítók és tanárok. Szinte minden jel arra mutat, hogy a Kárpát-medencei magyar iskolák zömében ez történik ma is.

\section{HOGYAN LEHETSÉGES MINDEZ?}

Hogyan lehetséges, hogy tanítók és tanárok ezrei anyanyelvi nevelés címén magyar kisiskolások és középiskolások tömegeit megszégyenítik, s bennük sokszor életre szóló traumákat okoznak? Hogyan lehetséges az, hogy egy Csepel-szigeti faluban egy hírneves nyelvmüvelő

20 ILLYÉs Gyula: Puszták népe. Osiris, Bp., 1999. 209-210.

21 Lásd: A szó becsülete: Iróink az anyanyelvról, 1541-1980. Szerk. Wacha Imre-Z. Szabó László. A Hazafias Népfront Országos Tanácsa, Bp., 1985. 106-108. (a továbbiakban Wacha-Z. Szabó szerk. 1985.)

22 Margócsy István: Magyar nyelv és/vagy irodalom: egy tantárgy kialakulása és változásai. Budapesti Könyvszemle 1996/1: 45-52. Az idézet az 52. oldalon olvasható.

23 Egy kétnyelvủ közösség élhet hozzáadó vagy felcseréló kétnyelvűségben. Az elóbbiben anyanyelvét szabadon használhatja, s ehhez hozzáadja az államnyelvet s annak használatát oly módon, hogy ennek anyanyelve nem látja kárát. A hozzáadó kétnyelvűségben a kisebbség nyelvi repertoárja bővül. A felcserélő kétnyelvűségben az államnyelv tanítása és használata az anyanyelv tanulásának és használatának kárára történik, ebben a helyzetben a kisebbség anyanyelve elsorvad. Egy egynyelvü közösség iskolájában a standard (irodalmi) nyelvváltozatot lehet hozzáadó vagy felcseréló módon tanítani. Az elő́bbiben a standard változat tanítása nem okoz kárt a növendékek anyanyelvváltozatában (a vernakulárisukban), de a felcserélő nyelvpedagógia a diákok legsajátabb, otthon tanult nyelvváltozatának kiiktatására törekszik. 
támogatásával az autokrata polgármester két pártra szakítja a falut? A település egyik része a hagyományos szigetújfalusi megnevezést használja ma is, a másik viszont a szigetújfalui helyességére esküszik, s eközben a plébános is bizonytalankodik a szószéken. ${ }^{24}$ Hogyan lehetséges, hogy - legalábbis a nyilvánosság előtt - nem ildomos rasszista, szexista stb. nézeteket hirdetni, de a magyar nyelvi alapú társadalmi diszkriminációt szinte senki nem helyteleníti, sőt, sokszor meg is tapsolják a lingvicista magatartást?25 (Hiszen az a magyar, aki félti, óvja édes anyanyelvünket, a nemzetet félti és óvja, akkor is, amikor más magyarok „helytelen” nyelvhasználatát kritizálja, s eközben e más magyarok intellektuális és morális defektusairól tesz gúnyos kijelentéseket.)

Minderre a válasz meglepően hangozhat: ez a sok nyomorúság a mi magyar kultúránkból fakad. Nyelvünk kultikus megközelítéseiről írt nagyszerű tanulmányában Margócsy bemutatja, miként alakult ki a 19. században „az az erkölcsi parancs, mely a nyelv ápolását hazafiúi kötelességként állítja be, s ennek feltételéül a nyelv iránt érzett érzelmi elfogultságot, szeretetet írja elö" ${ }^{26}$. Ehhez jön még, ebből is fakad az a helyzet, hogy nyelvünkről kellő pátosszal bármit lehet következmények nélkül állítani, „mintha a nyelv tisztelete, a nyelvről való beszéd kultikus hagyománya eleve kizárná, hogy a nyelvről ellenőrizhető állítások is tétessenek”. ${ }^{27}$

Kultúránk része az a szinte ájult tisztelet is, amely a magyar nyelvművelőket övezi. Akkor is így van ez, ha - Szilágyi axiomatikus állítását idézem - „a nyelvművelő a nyelvet védi (mégpedig, bármilyen különösen hangzik is, a beszélőkkel szemben)” ${ }^{28}$ Ehhez szerzőnk hozzáfüzi még (uo.), hogy a nyelvi képtelenségek egy része „azért jön létre, mert az emberek félnek a nyelvművelőktől. (Gondolkozzunk itt el ezen egy kicsit: miféle jogviszony az, ahol nagyon sok ember fél nagyon kevéstől, éspedig nyelvhasználati okokból? A politikában az ilyen helyzetet diktatúrának hívják - ezt vajon minek lehet?)” A hivatásos nyelvmúvelők kevesen vannak, de mivel a tanítók és tanárok túlnyomó többsége is nyelvművelő (Margócsyval szólva: az anyanyelv oktatása nyelvművelő funkciót lát el), ez a magyar társadalmi átok szinte mindenkit elér.

24 F. Dornbach Mária-Kontra Miklós: Falusi történet $=$ „... hogy legyen a viznek lefolyása $. . . ”:$ Köszöntó kötet Szilágyi N. Sándor tiszteletére. Szerk. Benő Attila-FazAKAs Emese-Kádár Edit, Kvár, Erdélyi Múzeum-Egyesület, 2013.99-119.

25 Az ilyen nyelvi diszkriminációt az angol James Milroy „a nyílt társadalmi diszkrimináció utolsó bástyájának” nevezte, lásd: SÁNDOR Klára: „A nyilt társadalmi diszkrimináció utolsó bástyája”: az emberek nyelvbasználata. Replika 45-46. szám (2001. november): 243-259.

26 Margócsy István: „Istennöm, végzetem, mindenem, magyar nyelv!”: A magyar nyelv kultikus megközelitései - 1. rész. Beszélő 2006/10: 95-109. Az idézet a 98. oldalon található.

27 MARGócsy István: „Istennöm, végzetem, mindenem, magyar nyelv!”: A magyar nyelv kultikus megközelitései - 2. rész. Beszélő 2006/11: 90-98. Az idézet a 95. oldalon.

28 Szilágyi N. Sándor: A többség nyelvi jogai = ANDor József-Szűcs Tibor-Terts István, szerk.: Szines eszmék nem alszanak.... Szépe György 70. születésnapjára. Lingua Franca Csoport, Pécs, 2001. 1209-1218. Az idézet az 1216. lapon. 
A nyelvhelyesség hiedelemrendszere ${ }^{29}$ olyannyira átitatta a magyar társadalmakat, hogy megfigyelhetjük ,az elme gyarmatosítását” is. Ezt a fogalmat egy afrikai tudós, Ngũgĩio alkotta meg, azt jelenti, hogy az elnyomott emberek magukévá teszik az elnyomók ideológiáját, $\mathrm{s}$ kvázi helyeslik az elnyomók cselekedeteit s ebból kifolyólag saját elnyomott helyzetüket is. Az elme ilyen gyarmatosítása megfigyelhető a magyarok esetében is, ki ne hallott volna ilyen pironkodó megjegyzést: Tudom, hogy helytelenül beszélek magyarul. Margócsy ${ }^{31}$ Révai Miklóstól Nagy Lászlóig idézi a „nem tudunk magyarul” típusú nyilatkozatokat. Hozzáteszem Illyéstố132 ezt:

„Amilyen örömmel, mindannyiszor majdnem ugyanolyan szorongással fogok szépen gyarapodó nyelvmúvelő művek olvasásába. Eleve örülök a jó íznek, amelyet egy-egy nyelvi fordulat kibontása révén élvezhetek, és szorongva, izgatottan futom át a pellengérre állított hibákat: hátha én is elkövettem azokat."

\section{MIT LEHET TENNI?}

Mit lehet tenni egy olyan ritka helyzetben, amikor minden magyar politikus egyetért abban, hogy nyelvünket óvni, védeni, művelni kell, s amikor a nyelvmúvelés és az iskolai anyanyelvi nevelés kívánatos módja tekintetében nincs szemernyi különbség sem - példának okáért Aczél György, ${ }^{33}$ Hiller István ${ }^{34}$ és Balog Zoltán ${ }^{35}$ közöttt? ${ }^{36}$

Mit lehet tenni olyan rendkívül visszás helyzetben, amikor „tekintélyes tudományos és államigazgatási intézmények egy olyan folyóiratot támogatnak, amely nyelvi múveltség helyett

29 Nem szeretném, ha az olvasó azt gondolná, szerintem/szerintünk egyáltalán nincs nyelvhelyesség. Van. Ha például valaki érthetetlen, értelmezhetetlen szöveget mond vagy ír, az helytelen. De a nálunk szokásos nyelvhelyesség igen gyakran a változatok létjogának korlátozott elismeréséből fakad, és tudományosan gyakran védhetetlen.

30 NGŨgĨ wa Thiongo: Decolonising the Mind: The Politics of Language in African Literature. London, James Currey, 1987.

31 Lásd: MARGócsy István: „Istennôm, végzetem, mindenem, magyar nyelv!”: A magyar nyelv kultikus megközelitései - 2. rész. Beszélő 2006/11: 90-98. Az idézetek a 96-97. oldalon.

32 Idézi: Wacha-Z. Szabó szerk. 1985.115.

33 Aczél György: Nyelvünk védelmében. Édes Anyanyelvünk 1979/4. szám: 1.

34 Hiller István: Uniós tagállamként is meg kell örizni a magyar nyelvet. http://hirkozpont. magyarorszag.hu/hirek/anyanyelv20040420.html/ (Létrehozva: 2004. április 20., Módosítás: 2004. április 21., Forrás: Magyarország.hu)

35 Balog Zoltán: 48. Szép magyar beszéd verseny: Balog Zoltán miniszter köszöntöje. Édes Anyanyelvünk 2013/3. szám: 20.

36 Ez a nagy egyetértés egyáltalán nem hungarikum. Az amerikai négerekkel (feketékkel) kapcsolatos nagy nyelvi viták kapcsán Walt Wolfram (Language Ideology and Dialect: Understanding the Oakland Ebonics Controversy. Journal of English Linguistics Vol.26(1998), No. 2: 111.) a következő költői kérdést fogalmazta meg: „Milyen más témában ért egyet egy olyan konzervatív ikon, mint a média híresség Rush Limbaugh és a társadalmi aktivista Jessie Jackson, ha nem a feketék beszélte angol nyilvános elítélésében?” (Saját fordításom, K. M.) 
babonaságot terjeszt"? Az idézetet Lanstyáktól ${ }^{37}$ vettem, aki elolvassa tanulmányát, abban szikrányi kétség se maradhat afelől, hogy a Magyar Tudományos Akadémia Magyar Nyelvi Bizottsága és a mindenkori oktatási és kulturális minisztériumok által támogatott Édes Anyanyelvünkre utal, Az Anyanyelvápolók Szövetsége folyóiratára.

Magától adódik az elsố válasz arra a kérdésre, hogy mit lehet, mit kell ilyenkor tenni. A tekintélyes tudományos és államigazgatási intézményeknek be kell szüntetniük a nyelvi babonákat terjesztő folyóiratok, kiadványok és szervezetek támogatását, s támogatniuk kell a tudományosan is megalapozott nyelvi múveltséget terjesztő folyóiratokat, kiadványokat és szervezeteket. Amint Lanstyák ${ }^{38}$ írta, a cél az, hogy „a jobb sorsra érdemes Édes Anyanyelvünk a nyelvi mítoszok, babonák és butaságok terjesztője helyett a szó legnemesebb értelmében vett nyelvi ismeretterjesztés és nyelvi tanácsadás értékes és értelmes fórumává váljon. És persze jó volna elérni, hogy a tudomány és a babonaság élesen elváljon egymástól, ne lehessen a kettő határán lavírozni, ahogy ezt sok, jobb sorsra érdemes nyelvész kollégám teszi." Ehhez persze elengedhetetlen, hogy ezek az intézmények képesek legyenek megkülönböztetni nyelvi kérdésekben is az ocsút a búzától, a társadalmilag kártékonyat a hasznostól; s az is, hogy a tudomány és a babonaság határán lavírozó nyelvészek elnémuljanak.

Szükségünk van sokkal több és hatékonyabb tudományos ismeretterjesztésre is. Vannak jó példák, többek közt Cseresnyési cikksorozata, ${ }^{39}$ Kálmán és Nádasdy könyve, ${ }^{40}$ Szilágyi két könyve is, ${ }^{41}$ de a rossz példák, a babonaságokat terjesztő fórumok társadalmi megbecsülése és támogatása nem csökken.

Nagy szükség van a tanító- és tanárképzés nyelvi komponensének modernizálására. Itt nem csak a magyartanárok, hanem minden tanár képzésére gondolok. Megint csak említhetek már jó példákat, így Kálmán pedagógusoknak írt cikkét, ${ }^{42}$ a Sándor által szerkesztett ${ }^{43}$ és Lanstyák által írt ${ }^{44}$ egyetemi tankönyveket, valamint Kugler és Tolcsvai Nagy iskolai tankönyvét ${ }^{45}$ és Beregszászi tantárgy-pedagógiai útmutatóját, ${ }^{46}$ de tanító- és tanárképzésünk egészét tekintve ezek csak cseppek a tengerben. Ráadásul azt is tudjuk mások tapasztalatá-

37 LANstyÁK István: Helyi „értékes” nyelvváltozatok, „tisztes” idegen szavak, „visszás” jelentések, „agreszszîv" röviditések, "kevercs” nyelv és társaik. Válogatás a nyelvmüvelói csacskaságok gazdag tárbázából, I. Fórum Társadalomtudományi Szemle 2003/4: 70.

38 Az előző jegyzetben idézett helyen.

39 Lásd például: Cseresnyési László: Játszik velünk a nyelv. Magyar Narancs 2013/3. szám: 48-49.; Uő: Nyelvünk ösi vére. Magyar Narancs 2013/51-52. szám: 116-117.

40 Kálmán László-NÁdAsDY Ádám: Hárompercesek a nyelvröl. Osiris, Bp., 1999.

41 SzILÁgyi N. Sándor: Ne lógasd a nyelvedet hiába!: Nyelvtani kiskalauz felvételizóknek. Anyanyelvápolók Erdélyi Szövetsége, Kvár, 2000; Uő: Világunk, a nyelv. Osiris, Bp., 2000.

42 Kálmán László: Mit müvelünk? Taní-tani 2010/1. szám: 3-11.

43 Nyelv és hatalom, nyelvi jogok és oktatás: Tanulmányok a Bolyai Nyári Akadémia elóadásaiból. Szerk. SÁndor Klára, „Apáczai Csere János” Pedagógusok Háza, Csíkszereda, 2000; Nyelv, nyelvi jogok, oktatás: Tanulmányok a társasnyelvészet oktatásához. Szerk. Uő,JGYF, Szeged, 2001.

44 Lanstyák István: Nyelvmüvelés, nyelvtervezés, nyelvmenedzselés. STIMUL, Pozsony-Bratislava, 2009.

45 Kugler Nóra-Tolcsvai Nagy Gábor: Magyar nyelv: tankönyv 14-15 éveseknek. Korona, Bp., 1998.

46 Beregszászi Anikó: A lehetetlent lehetni: Tantárgy-pedagógiai útmutató és feladatgyújtemény az anyanyelv oktatásához a kárpátaljai magyar iskolák 5-9. osztályában. Tinta, Bp., 2012. 
ból, ${ }^{47}$ hogy amikor egy országban sikeresen megváltoztatják a tanárképzést és a tanárok gondolkodását, amint történt ez Angliában az 1970-es években, ha kiveszik a tanárképzésből a nyelvi változatosság és türelem komponensét, akkor automatikusan újraéled a régi, elitista és diszkriminatív anyanyelvi nevelés. Ha tanárképzésünket megváltoztatjuk, akkor a magyar iskolák - amelyek ma is a nyelvi alapú társadalmi diszkrimináció kialakításának legfőbb színterei - is megváltozhatnak, s a jövőben az előítéletek táplálta diszkrimináció csökkentésének intézményei lehetnek.

\section{HOW CAN IT BE THAT ALL HUNGARIANS, FROM THE HUNGARIAN ACADEMY OF SCIENCES TO BARTENDERS, SUPPORT THE LINGUISTIC DISCRIMINATION OF HUNGARIANS BY HUNGARIANS?}

\section{Keywords: Hungarian Academy of Sciences, language-based social discrimination, linguicism, Hungarian language cultivation, Codified Standard Hungarian, Hungarians in the Carpathian Basin, teaching grammar in schools, subtractive and additive language pedagogy, teacher education}

Hungarians live in what James Milroy (1999) calls standard language ideology, that is a society in which the superiority of codified standard Hungarian is maintained and recreated through various channels of communication, including public education. Other varieties of Hungarian and their speakers (both in Hungary and her neighboring countries) are badly stigmatized by the propagators of codified standard Hungarian, who include almost all Hungarians from the Academy through school teachers to bartenders and beyond. This massive language-based social discrimination is deeply rooted in Hungarian culture, which has cherished the notion of "correct Hungarian" as a guarantee for the survival of the nation since the 19th century. Data from the Hungarian National Sociolinguistic Survey conducted in 1988 show that from 50 to $90 \%$ of a representative sample of Hungarians in Hungary make judgments of grammatical correctness and use constructions in speech which are in violation of the codified standard. This means that traditional language cultivators and almost all school teachers are engaged in trying to change the speechways of about two in three Hungarians in Hungary, and more in the neighboring countries, where Hungarians speak contact dialects different from the monolingual varieties in Hungary. The author suggests three ways to change the language-based social discrimination pertaining in Hungarian speech communities: (a) the Hungarian Academy should cease supporting language mavens who spread false linguistic ideologies, (b) professional linguists should successfully popularize sound linguistic knowledge, and (c) teacher education should be reformed such that additive language pedagogy supplants the all-pervasive subtractive pedagogy (in which standard Hungarian is taught at the cost of, rather than in addition to, the pupils' own language varieties).

47 Lásd: Kontra Miklós-Peter Trudgill: If Women Are Being Discriminated Against, You Don't Say "You Should Become a Man": An Interview with Peter Trudgill on Sociolinguistics and Standard English. novELTy 7/2(2000): 17-30. 


\title{
CUM SE POATE CA TOŢI MAGHIARII, DE LA ACADEMIA MAGHIARĂ DE ŞTIINŢE DIN PÂNĂ LA BARMANI, SUSŢIN DISCRIMINAREA LINGVISTICĂ A MAGHIARILOR DE CĂTRE MAGHIARI?
}

\section{Cuvinte-cheie: Academia Maghiară de ştiinţe din Ungaria, discriminare socială pe bază de limbă, lingvicism, cultivarea limbii maghiare, limba maghiară standard codificată, maghiarii din Bazinul Carpatic, predarea gramaticii în școli, pedagogia substractivă şi aditivă a limbii, formarea profesorilor}

\begin{abstract}
Maghiarii trăiesc în ceea ce James Milroy (1999) numește ideologia unui limbaj standard, care definește o societate în care se menţine superioritatea variantei codificate a limbii, această ideologie fiind recreată prin diverse canale de comunicare, inclusiv prin educaţia publică. Celelalte variante ale limbii maghiare și vorbitorii lor (atât în Ungaria cât și în ţările învecinate) sunt grav stigmatizate de către propagatorii variantei codificate, standardizate a limbii maghiare, între aceștia numărându-se aproape toţi membri Academiei, și numeroși cetăţeni de la profesorii la barmani, și nu numai. Această masivă discriminare socială pe bază de limbă este adânc înrădăcinată în cultura maghiară, care, încă din secolul al 19-lea, a considerat noţiunea de „maghiara corectă”, ca o garanție pentru supravieţuirea naţiunii. Rezultatele Studiului Naţional de Sociolingvistică efectuat în Ungaria în 1988 arată că 50-90\% dintr-un eșantion reprezentativ de maghiari din Ungaria face judecăţi privind corectitudinea gramaticală, iar în vorbire folosește fraze sau construcţii gramaticale care contravin standardului codificat. Acest lucru înseamnă că, tradiţionalii cultivatori ai limbii maghiare și aproape toate cadrele didactice din învăţământul preuniversitar se implică în încercarea de a schimba modul de vorbire al aproximativ doi din trei maghiari în Ungaria, precum și în ţările vecine, unde maghiarii vorbesc diferite variante de contact faţă de variantele monolingve din Ungaria. Autorul propune trei modalităţi de a schimba discriminarea socială pe bază de limbă existentă în comunităţile vorbitoare de maghiară: (a) Academia Maghiară de Știinţe ar trebui să înceteze susţinerea experţilor în lingvistică care răspândesc ideologii lingvistice false, (b) lingviștii profesioniști ar trebui să popularizeze cunoștinţe lingvistice sănătoase, și (c) formarea cadrelor didactice ar trebui să fie reformată astfel încât pedagogia aditivă a limbii să înlocuiască pedagogia substractivă (aplicată peste tot) a limbii (în care varianta standard a limbii maghiare este predată, mai degrabă în detrimentul limbii vernaculare a elevilor, decât ca un plus faţă de această variantă).
\end{abstract}

